\title{
Illiberal Secularism. Fake Inclusion through Neutrality*
}

\author{
Secularismo iliberal. La fallida inclusión mediante la neutralidad
}

\author{
Carmen Innerarity Grau \\ Universidad Pública de Navarra \\ carmen.innerarity@unavarra.es
}

doi: http://dx.doi.org/10.18543/ced-59-2018pp45-61

Contents: I. Introduction.-II. Citizenship and secularism: between universalism and particularism.-III. A threatened identity.-IV. An example: Muslim religious symbols.-V. Conclusion.-VI. References.

\begin{abstract}
This paper analyses how, despite the universalist and inclusive vocation of secularism, this has become the main argument for the exclusion of Muslim religious practices, with the consequent limitation of individual liberties. Thus, an institution thought as a procedure to guarantee the equality of the citizens through the differentiation between the political and religious spheres becomes a feature that defines the identity of Europe and that it is necessary to defend against the accommodation demands raised by Muslim immigrants. Obviously, it is not possible to establish a cause-effect relationship, but the climate of hostility towards the cultural difference spread by the entry into several European polities of radical right parties, clearly hostile to Islam and Muslims, could be influencing, in some way, the political orientation of European governments in this regard.
\end{abstract}

Keywords: Multiculturalism, immigration, citizenship, secularism.

Resumen: Este artículo analiza el modo en que, a pesar de su vocación universal e inclusiva, el secularismo se ha convertido en el principal argumento para la exclusión de prácticas religiosas musulmanas con la consiguiente limitación de las libertades individuales. Así, una institución concebida como un procedimiento para garantizar la igualdad de los ciudadanos mediante la diferenciación de las esferas política y religiosa, se vuelve una característica que define la identidad europea y que debe defenderse frente a los reclamos de acomodación planteados por los inmigrantes musulmanes. Si bien todo indica que no es posible establecer una relación causa-efecto, el clima de hostilidad hacia la diferencia cultural que se abre paso con el auge de partidos de extrema derecha en Europa, con un rechazo hacia el Islam y los musulmanes, podría estar influenciando, hasta cierto punto, la orientación política de algunos gobiernos europeos en esta materia.

Palabras clave: Multiculturalismo, inmigración, ciudadanía, secularismo.

* Recibido el 17 de diciembre de 2017, aceptado el 8 de mayo de 2018. 


\section{Introduction}

The countries of Europe are defining their way of managing cultural pluralism in a context marked by discourses and policies that oscillate between the universalism of human rights as inspired by European institutions - as well as the materialization of those rights in institutions such as citizenship and state neutrality - and the nationalist, exclusionary particularism that is disseminated by parties of the extreme right, among others. These circumstances place us at a crossroads where what is at play is not only the ability of our institutions to integrate, but our commitment to the values of the Enlightenment and liberal democracy that are at the core of the European project.

This paper presents some of the difficulties affecting the management of the religious diversity that has been created by immigration in Europe beginning with a conceptual analysis of two institutions that have helped us guarantee equal status to all members of a political community, regardless of their identity, and, more specifically, to accommodate the beliefs of minority groups: citizenship and secularism. Are these two institutions truly inclusive under current circumstances? To what extent do they help us manage cultural and religious diversity in a context of immigration? Despite their universalist, inclusive vocation, both institutions have an exclusionary and particularistic side, as has been revealed in the question of religious symbols in Europe.

This paper will also reflect, more specifically, on the reason European countries have chosen to ban Islamic religious symbols in the public space, even though their commitment to the universalism of neutrality and citizenship should have made them guarantee Muslims the same status as those who maintain majoritarian beliefs. I defend the thesis that political debates on this question have ended up imposing a particularism with two manifestations.

First, a "moderate"1 or "modest" 2 secularism, in which Christian references remain, at least, as a cultural trait that we need to keep for the sake of social cohesion. Second and most common, a specific version of secularism that moves beyond merely being an institutional procedure for achieving equality and ends up becoming a trait that defines the identity of Europe/ the country and that it is necessary to defend against the Other, in this case, Muslims and their demands of accommodation. In this way, an institution

1 Tariq Modood, "Multiculturalism and Moderate Secularism", Robert Schuman Centre for Advanced Studies Research Paper No. RSCAS 2015/47 (2015).

2 Rajeev Bhargava, "How Secular Is European Secularism?", European Societies 16, 3 (2014): 329. 
that, in principle, would have an inclusive character turns into the main argument for the exclusion of certain practices.

It is obviously not possible to establish a cause-effect relationship, but the climate of hostility toward cultural difference that has been spread by having radical right parties that are clearly hostile to Islam and Muslims enter into several European polities could, in some way, be influencing the political orientation of governments in this regard.

\section{Citizenship and secularism: between universalism and particularism}

The increase and greater visibility of religious diversity in Europe as a consequence of immigration has made evident the tensions between the different components of what some authors have called the "Holy Trinity of Modernity"3, in other words, the inseparable union between state (sovereignty, territory), nation (cultural identity) and citizenship (rights) ${ }^{4}$. This institution that has, since modernity, helped us organize belonging and equality in the entitlement of rights contains a contradiction between universal inclusion and particularistic exclusion. If the goal of citizenship is to guarantee the equality of rights, overcoming the "hereditary distinctions" that the 1791 French Constitution believed to be surmounted by "the common rights of the French", its logical consequence is the inclusion of individuals regardless of their specific identity. A concrete institutional embodiment of this universalism is state neutrality when it comes to different religious creeds. But this universalist project contains the "paradox of political modernity", which is that its effective realization depends upon belonging to a particular national state with its territorial and identity demarcations which, therefore, excludes from physical and symbolic state borders any individuals and cultures that are different.

The context in which the European countries face the management of the religious diversity that is generated by immigration is characterized by the confrontation between those two aspects of citizenship. In the first place, universalism - the logic of inclusion as equals - which is inscribed in the very definition of citizenship and is, beyond mere academic debates, ad-

${ }^{3}$ Gerd Baumann, El enigma multicultural. Un replanteamiento de las identidades nacionales, étnicas y religiosas (Barcelona: Paidós, 2001).

${ }^{4}$ Dominique Schnapper, La comunidad de los ciudadanos. Acerca de la idea moderna de nación (Madrid: Alianza, 2001).

5 Andreas Wimmer, Nationalist exclusion and ethnic conflict: Shadows of modernity (Cambridge: University Press, 2002). 
vocated by both the Council of Europe and the European Union in its directives on the integration of immigrants.

Thereby, the White Paper on Intercultural Dialogue, "Living Together as Equals in Dignity", launched by the Council of Europe in 2008 on the occasion of the celebration of the year of intercultural dialogue, set a range of principles and values that should guide the governance of cultural pluralism, underscoring "the dignity of every human being, over and above the entitlements enjoyed by individuals as citizens of a particular state" 6 . Thus, the paper continues, "no undue restriction must be placed on the exercise of human rights, including by non-citizens. Given the universal character of human rights, of which minority rights - inter alia cultural, linguistic and participatory rights - are an integral part, it is of utmost importance to ensure the full enjoyment of human rights by everyone"7. In the field of the European Union, with its goal of affording "fair treatment of third country nationals who reside legally on the territory of its Member State", the Tampere European Council recommended "granting them rights and obligations comparable to those of EU citizens" , from which the recognition of rights derives, regardless of the possession of citizenship. Along the same lines, The Common Basic Principles for Immigrant Integration Policy in the EU, adopted in November 2004, setting the foundations of EU initiatives in the field of integration, declares that "the practice of diverse cultures and religions is guaranteed under the Charter of Fundamental Rights and must be safeguarded, unless practices conflict with other inviolable European rights or with national law"

In opposition to this universalism, there is a tendency toward particularism, a "neo-nationalism" 10 that is manifested in two senses. In the first place, although the Tampere Summit recommends that the legal status of thirdcountry nationals be as similar as possible to the status of citizens, in fact, belonging to a particular national community is what guarantees "the right to have rights" and not the mere gratuitous concession of areas of free action which are, therefore, reversible on the part of governments. In other words, citizens are the only ones entitled to demand rights from the state and to file

${ }^{6}$ Council of Europe, White Paper on Intercultural Dialogue. Living Together as Equals in Dignity (2008): 17.

7 Ibidem 41.

${ }^{8}$ Council of the European Union, Tampere European Council 15 and 16 October 1999. Presidency Conclusions (1999).

${ }^{9}$ Council of the European Union. Common Basic Principles for Immigrant Integration Policy in the EU (2004).

10 Per Mouritsen, "Beyond postnational citizenship. Access, consequence, conditionality", in European multiculturalisms: Cultural, religious and ethnic challenges, ed. by Anna Triandafyllidou, Tariq Modood and Naser Meer (Edinburgh: University Press, 2011), 88-115. 
a claim if they find themselves deprived of some of them; fundamentally, the right to enter and settle in a territory, the right to enjoy the benefits of the welfare state and finally, regarding our topic of concern, the right-beyond mere tolerance - to recreate their own cultural and religious practices. This is the underlying logic of discourses that emphasize a national preference when it comes to access to the labour market or social benefits.

In addition, universalism and the resulting tendency toward inclusion also conflict with the need to safeguard the cultural values that define belonging and social cohesion in this specific country, which is also derived from the institutional articulation of the idea of citizenship that I referenced above. Furthermore, in the current context, this concern about identity refers, fundamentally, to the integration of people of Muslim origin, who are perceived as bearers of values that are completely foreign to the Western democracies.

Both the idea of national preference and the need to defend the values that are the basis for social cohesion are characteristic of the discourse of the extreme right, which, in some sense, could be creating a climate of opinion that is opposed to diversity, affecting the policies for managing cultural pluralism in Europe ${ }^{11}$. It is this second aspect-the opposition to cultural pluralism - that it is most interesting to analyse for this paper.

\section{A threatened identity}

One of the slogans of the Front National is "the identity imperative" ("L'imperatif d'identitê") ${ }^{12}$, which alludes to the culture that defines us and that we need to defend from foreign threat. That identity is considered, first of all, as a homogeneous block, that does not, consequently, accept cultural pluralism. Therefore, the reference to "German as dominant culture instead of multiculturalism" (Deutsche Leitkultur statt Multikulturalismus) has been a recurring slogan for that country's extreme right for years, highlighted by Alternative für Deutschland ${ }^{13}$, as Die Republikaner previously $\operatorname{did}^{14}$. Furthermore, an expression of the actual political influ-

${ }^{11}$ Innerarity, Carmen and Beatriz Acha. "Los discursos sobre ciudadanía e inmigración en Europa: universalismo, extremismo y educación”, Política y Sociedad, 47 (2010): 63-84.

12 Front National (FN). 144 Engagements présidentiels (2017).

13 Alternative für Deutschland. Program für Deutschland (2017).

14 Manz, Stefan. "Constructing a normative national identity: The Leitkultur debate in Germany, 2000/2001”, Journal of Multilingual and Multicultural Development, 25, 5 (2004): 481-496; Bassan Tibi Europa ohne Identität? Die Krise der multikulturellen Gesellschaft (München: Bertelsmann, 1998); Basan Tibi "Die Ideologie des Multikulturalismus, nicht die Idee der kulturellen Vielfalt ist in der Sackgasse", in Multikulturalismus: Vision oder Illusion?, Heinrchh Böll Stiftung. Heimatkunde. Migrations Politisches Portal (2010). 
ence of the right-wing parties is the fact that this kind of topic has spread from the far right to other parties. Thus, for example, the CSU also advocates for the German Leitkultur, while explicitly rejecting multiculturalism. "Integration means being guided by our Leitkultur, not by multiculturalism; we reject multiculturalism" 15 , as the platform prepared for the recent parliamentary elections vehemently affirms. In the same way, the Österreichische Volkspartei $(\ddot{O} V P)$, the Austrian Christian-Democratic party, which has just agreed to form a coalition government with the Freiheitliche Partei Österreichs (FPÖ), as it already did between 1999 and 2002, points out in its electoral platform: "The FPÖ is committed to the homeland, the native people and to protecting Austrian Leitkultur"16.

This defence of identity is based on a concept of Europe/the country not only as a homogeneous block, but also as a static identity that draws only from its Greco-Roman origins and that has remained unaffected for centuries by the presence of peoples with different cultural baggage. In addition, since the expulsion of the Jews and Muslims from Spain in 1492, the contrast between us - the Europeans - and the Other, among whom the Muslims play a leading role, has been continually strengthened, not only in that country, but all around Europe (Martín Muñoz 2012). That is why, for example, AfD's platform emphasizes the idea that "Islam does not belong to Germany"17, echoing the polemic that arose in that country in 2010 as a result of the declarations of then president of the Republic, Christian Wulff, on the occasion of the commemoration of the twentieth anniversary of German unification. This generated an important debate in German public opinion, and Angela Merkel herself intervened various times, until recently closing the discussion that had even been launched in the heart of her own party, affirming categorically in the electoral debate with Schulz last summer that Islam belongs to the German society ${ }^{18}$.

In any case, an "identitarian movement"19 underlies the rejection of Muslim immigration. If the stigmatizing of immigrants in the 1980s primarily referred to "social danger", the turn of the century has produced a "transformation of the social question of integration into an unsurmountable and antagonistic question of identity" 20 .

\footnotetext{
15 Alternative für Deutschland. Program für Deutschland (2017).

16 Österreichische Volkspartei. Wahlprogram (2017).

17 Alternative für Deutschland. Program für Deutschland (2017).

$18 \mathrm{https} / / / w w w . z d f . d e / p o l i t i k / w a h l e n / t v-d u e l l-m e r k e l-s c h u l z-100 . h t m l$

19 Sami Naïr, Refugiados. Frente a la catástrofe humanitaria, una solución real (Barcelona: Crítica, 2016): 138.

${ }^{20}$ Ibidem 136.
} 
More precisely, since the 1990s, there is a tendency in Europe to label immigrants based on their religious identity rather than ethnic or geographic origin. This also occurs in a context in which the debates are centred on Muslims and on the possibility of their integration, at the same time as their religion is associated with a strong potential for conflict. That is why there is a rejection of "religiously dangerous" immigrants, thus reinforcing the contrast between us and the Other: Islam as opposed to the values of Western democracy. This is an "acculturation of social problems" 21 that attributes any controversial question to religious beliefs and to group identity. Muslim immigrants, considered the principal bearers of values that are different and even contrary to those held by Western democracies, are now the principal target of a discourse filled with islamophobia, which acquires particular force at a time characterized by the social crisis, insecurity, unemployment and, especially, the crisis of institutions that used to contribute to social integration, such as schools, labour unions or political parties $^{22}$.

In these circumstances, the presence in the public space of immigrants who are labelled as members of a religious group and their claims-making upon European governments are both viewed as a specific challenge to Western identity. "The religious Other now seems to be the immigrant that shows belief in public, one whose observance is revealed in public through particular social uses and by their way of dressing"23. That "deprivatization of religion" 24 , aiming for public recognition, especially of a non-European religion, is leading to an increase of assertions in European societies of both a "Christian cultural identity" 25 and, further still, of Enlightenment secularism. As Angela Merkel stated: "We feel tied to Christian values. Those who don't accept them don't have a place here"26. This is a cultural affirmation of Christian values, which does not necessarily have to be accompanied by an increase in religious practice, as Giscard d'Estaing noted about

21 Anna Triandafyllidou, "Diversity, Integration, Secularism and Multiculturalism", in European Multiculturalisms, ed. by Anna Triandafyllidou, Tariq Modood and Naser Meer (London: Palgrave, 2011): 47.

${ }^{22}$ Michel Wieviorka, El racismo. Una introducción (Barcelona: Gedisa, 2009).

23 Moreras Jordi, "Migraciones y pluralismo religioso. Elementos para el debate". Documentos CIDOB Migraciones n. 9 (Barcelona: CIDOB, 2006): 50.

${ }^{24}$ José Casanova "Immigration and the new religious pluralism", in Secularism, religion and multicultural citizenship, edited by Geoffry Brahm Levey and Tariq Modood (Cambridge: University Press, 2010): 141.

25 Tariq Modood 'Post-Immigration 'difference' and Integration: The Case of Muslims in Western Europe", in New Paradigms in Public Policy, ed. by Peter Taylor-Gooby (Oxford: University Press, 2013): 51.

${ }^{26} \mathrm{http} / / / \mathrm{www} . v 0 x e u r o p . e u / d e / c o n t e n t / a r t i c l e / 363851-m u l t i k u l t i-e i n-w o r t-i s t-t o t$ 
the inclusion of a symbolic reference to Christianity in the preamble to the failed European constitution: "I never go to church, but Europe is a Christian continent". Europe is seen, thus, as a "secular Christian" 27 entity. It is a belonging without believing, in the sense that the religious tradition remains inscribed in the social memory, although it is not necessarily expressed through observance. These religions endure "as significant cultural systems and as imagined communities in competition with other imagined national communities"28. This explains, for example, the fact that Europeans may protest against the construction of mosques, even if they never set foot in a church $^{29}$.

But, in addition, Islamic immigrants and religious practices generate rejection not only because of being an expression of religious otherness but, especially, because of their religiosity itself, because of their otherness in relation to European secularization: it is not the private practice of religion but its presence and visibility in the public sphere and their claims-making in the Western secular state. Secularism considered "as a quasi-normative consequence of being a modern and enlightened Europe" 30 . Secularism is, thus, not only a means to protect religious freedom in its different aspects and expressions but has indeed become "a mark of western identity" 31 . Logically, in this context, labelling a group by their religious identity-as is the case with immigrants from Muslim countries-and their demands for accommodation in the public sphere seem to erode the separation that secularism has attempted to establish between the political and religious spheres that is "part of a narrative of western exceptionality" 32 . Therefore, distrust toward Muslim communities does not stem so much from the mere fact of religious otherness, nor is it even a result of it being a non-Christian and non-European religion, which is also true, but more than anything from their religiosity, which is seen as "the Other" against which European secularity must be defended.

Both aspects - Christianity and secularism - are emphasized by the extremists in their defence of national identity. On the one hand, some platforms reference Christianity expressly as an integral aspect of European identity, which clearly contrasts with Islam. In their platform, AfD affirms:

27 Modood, "Post-Immigration 'difference' and Integration: The Case of Muslims in Western Europe", 53.

28 José Casanova, Religiones públicas en el mundo moderno (Madrid: PPC, 2004): 30.

${ }_{29}$ Moreras, "Migraciones y pluralismo religioso. Elementos para el debate", 16.

30 Casanova, "Immigration and the new religious pluralism", 144.

${ }^{31}$ S. Sayyid "Contemporary politics of secularism", in Secularism, religion and multicultural citizenship, ed. by Geoffry Brahm Levey and Tariq Modood (Cambridge: University Press, 2010): 188.

32 Sayyid, "Contemporary politics of secularism", 189. 
"This culture is derived from three sources: the first of which is the Christian religious tradition". FPÖ emphasizes: "Christianity, the foundation of Europe". But, beyond these allusions to the Christian religion, they all hold that secularism is an important aspect of European identity that is supposedly in danger and that needs to be protected from external threats, fundamentally Islam and its demands. Evidence of that close relationship between secularity and identity is the fact that, in $F N$ 's platform for the last presidential elections, the reference to neutrality is found within the chapter dedicated to identity. "The nation through identity" ("La nation par l'identité"), it proclaims, in clear agreement with the typically French idea that la laïcité - the local version of state neutrality - is a characteristic aspect of national identity.

These references both to Christian values and to secularism as a mark of European identity reveal the "neo-nationalism" to which I have alluded previously. A particularism which could have led to restrictive measures when it comes to Islamic claims, in particular, the measures regarding Islamic religious symbols adopted by several European countries, even though their commitment to universalism and neutrality should have led them to guarantee Muslims the same status as members of the majority group in the exercise of their religious freedom.

\section{An example: Muslim religious symbols}

All Western democracies respect and protect the private practice of religion, including Islam, as a fundamental individual right, and this is the meaning of state neutrality.

We can define secularism in general as a political regime that establishes a separation between politics and religion, states and religious creeds, with the goal of protecting the equality of individual rights. However, problems arise when we try to determine with greater precision what neutrality means or to apply it to the management of concrete questions, such as the conflict stemming from the publication of caricatures of Muhammad or from the use of the Islamic veil. As a general rule, each European country has recreated its particular model of the separation between church and state and the accommodation of its minorities, with consequences that are more or less hospitable to the presence of religion in the public space. In France, la laïcité demands the strict privatization of religion. Great Britain maintains the Official Anglican Church, but it has shown great openness toward religious diversity. Germany recognizes the social function of religions and allows them to appear in the public sphere, insisting, at the same time, on the importance of the Christian tradition for social cohesion. 
But, regardless of the different national styles of managing religious diversity, the challenge perceived in the public and collective practice of Islam has led secularism reveal its most particularistic and excluding face. That is why the tendency here has been quite restrictive regarding the presence of Islam in the public space, demanding it be confined to the private sphere, paradoxically, with the goal of protecting the European tradition of liberal tolerance from the antiliberal and fundamentalist threat that is perceived in Muslim immigrants.

This is, for example, the case in France. In the first conflicts that arose in that country at the end of the 1980s, the Islamic veil was tolerated out of a liberal understanding of secularism. In this sense, it is an institution whose purpose is to safeguard individual rights, more specifically, the equal treatment of religions and equality in the freedom of religious practice, both in its negative and its positive sense. It is, then, a universalistic institution that aims to include individuals without considering their identity. However, following the report of the Stasi Commission in 2003, the law on religious signs of 2004 banned "conspicuous symbols", the symbols that make identity differences visible in the public sphere, overturning the previous liberal tolerance for the headscarf. This law, then, includes a republican understanding of secularism, according to which citizens must leave behind their religious identity or community belonging before entering the public sphere. This secularism "is part of our collective history" 33 , "it is an element of the republican pact" 34 , a political project in which individuals become free to engage in public life without the impediment of ascribed religious membership. La laïcité is a concept that has been developing over time, and it is now seen as a thread that defines French identity that must be defended against the visibility of religious belonging that derives from the use of the veil ${ }^{35}$.

The ban on ostensible religious symbols in France constitutes, in this way, an extreme example of illiberal secularism, which imposes important costs to religious liberty based on the defence of the political project that defines us and includes secularism as a fundamental feature.

In the case of Germany, there have been two arguments present in the debate about the Islamic veil. The first of them is neutrality understood in

${ }^{33}$ Bernard Stasi, Commission de réflexion sur l'application du principe de lä̈cité dans la Republique: rapport au Président de la République (2003): 1.1.

34 Stasi Commission 2003, 1.2.2.

35 Carmen Innerarity, "La polémica sobre los símbolos religiosos en Francia. La laicidad republicana como principio de integración”, Revista Española de Investigaciones Sociológicas, 111 (2005): 160; Jocelyn Maclure and Charles Taylor, Laicidad y libertad de conciencia (Madrid: Alianza, 2011): 26. 
two different and yet complementary fashions. In the first place, as a distancing of the state from religion, which does not imply the prohibition of any religious manifestation in the public space, but - in the second senseit is a positive secularity, open to religious fact and to the plurality of convictions: a "disposition open to protecting the freedom of all religious creeds to the same extent ... to guarantee space for the active acknowledgement of religious convictions" 36 . This way of understanding neutrality would imply a general acceptance of the presence of symbols from any creed in the public space and promoting, at the same time, equitable treatment for all of them. It would, therefore, be an institution with a universalist and inclusive nature. But, in a similar fashion to what has taken place in France, this universalist argument of the debate has confronted a second element of an identity-based and, therefore, exclusionary nature. If it was, in France, republican secularism understood as one of the country's defining characteristics, here it is the idea of Germany as a society based on Christian traditions and values. This is expressly stipulated in the constitutions of some Länder, such as North Rhine-Westphalia: schools shall educate children, "on the basis of Christian educational and cultural values and shall be open to Christian denominations and to other religious and ideological convictions" 37 , combining that sense of open and inclusive secularity and the express reference to Christian values as something that the education system should transmit with an eye to social cohesion. However, this final argument, along with an idea of exclusionary neutrality, is what led sixteen Länder to prohibit religious symbols, with the exception, in some of them, of religious symbols from Western traditions ${ }^{38}$. The case of Germany is, thus, a clear example of that "moderate secularism" 39 , which defines a style of "flexible separation" 40 and which is the model that actually exists in most European countries.

36 Bundesverfassungsgericht, 2 BvR 1436/02 Absatz-Nr. (1-140) (3.6.2003): 43.

37 Verfassung für das Land Nordrhein-Westfalen, art. 7.1. https://recht.nrw.de/lmi/owa/ br_bes_text?anw_nr=2\&gld_nr=1\&ug1_nr=100\&bes_id=3321\&aufgehoben=N\&menu= $1 \& \operatorname{sg}=0$. Art. 12

${ }^{38}$ In fact, in 2015, the German Constitutional Court found unconstitutional both the general prohibition - because it infringes upon the fundamental rights of the Constitution - and especially the selective prohibition - for being discriminatory. It must be examined whether state neutrality is actually in question in each particular case (Bundesverfassungsgericht $1 \mathrm{Bv} R$ 471/10 (27.01.2015).

39 Modood, "Multiculturalism and Moderate Secularism", 2015.

40 Philippe Portier, "State regulation of religion in Western European countries", in François Foret and Xabier Itçaina, eds. of Politics of religion in Western Europe. Modernities in conflict (London: Routledge, 2012): 99. 
In both countries, particularism has prevailed over universalistic procedures that exist in their respective political cultures and that would have allowed an open attitude toward diversity. It is a liberal understanding of secularism, seeking equal protection of individual liberty in France, or, in Germany, the idea of open neutrality and positive secularism, which guarantees the same status to different creeds. These are institutional procedures that not only seek the separation of church and state, but also - and perhaps more appropriately for managing current religious pluralism-seek to ensure equal treatment of all religions. However, in both of them, the debate between universalism and particularism has ended up stressing the latter, with the consequent inability to manage pluralism in an inclusive way. For this reason, both countries abandon the universalist goal inscribed in the institutions of citizenship and neutrality. In Germany, it has been the idea of the Christian tradition as a feature of its identity that must be protected against religious pluralism in order to guarantee social cohesion. In France, it is secularism also seen as a defining feature of its identity. Both France and Germany have made decisions that help reinforce the division between us and them. In France, between us - secularists - and them-groups that are looking for public recognition through permission for their specific way of dressing. In Germany, between us - cultural Christians - and themgroups that portray a religion we see as strange. Policies developed in both countries are a challenge to pluralism and equality and both "threaten to create a long-term racialised-religious division in Europe" 41

\section{Conclusion}

In addition to references to the Christian Western tradition in Germany, the fundamental argument for exclusion has been secularism. A secularism that has moved from being a procedural institution for the protection of equality and religious freedom to become a specific feature of European identity that must be defended, in this case, against Islam and Muslims. It is a "fundamentalist secularism" 42 , encouraged by the extreme right, among others, and manifested in illiberal measures of restricting religion liberties in the public space, demanding Islam be confined to the private sphere. A liberalism that transforms into an identity, an ethical way of life to which everyone is expected to conform and with exclusionary effects in liberal-

${ }^{41}$ Modood "Post-Immigration 'difference' and Integration: The Case of Muslims in Western Europe", 54.

42 June Edmunds, "The limits of post-national citizenship: European Muslims, human rights and the Hijab". Ethnic and Racial Studies, n. 35, 7 (2011). 
ism's presumed "Other", that is Islam and its claims in the public sphere. A liberalism which is in the core of European values and which, with a universalist language - such as the language of secularism, becomes, in fact, an ideology that is particularistic and exclusionary.

Therefore, and to conclude, I would like to emphasise two ideas. In the first place, European governments should pay attention, not so much to the procedure - secularism-as to the aims that this institution intends to achieve - the freedom and equality of individuals. Current debates on this subject tend to focus more on procedure than on values, turning secularism into something to be defended at any price, and not into a means that needs to be defined according to its capacity to achieve its intended ends: equality and freedom, beyond individual identity.

Second, we need to rethink the meaning of secularism in the current circumstances, a concept developed in and for a context of single-religion societies and which aimed at the separation of church and state, religion and politics. The goal of that procedure today is not only the differentiation of spheres, but granting the same status to the plurality of religions that live in Europe. The governance of multicultural societies requires, thus, a great effort by governments to formulate more positive and less defensive narratives about the increasing cultural diversity of Western societies. Therefore, Europe should move from viewing Islam as a threat to secularism to considering it as an opportunity to shift to a concept of secularism more appropriate to a context of deep religious pluralism, otherwise Muslim citizens will continue to face disadvantages due to their religious membership.

\section{References}

Alternative für Deutschland. Program für Deutschland (2017), available at https:// www.afd.de

Bhargava, Rajeev. "How Secular Is European Secularism?”, European Societies 16, n. 3 (2014): 329-36. doi:10.1080/14616696.2014.916335

Brahm Levey, Geoffrey. "Secularism and Religion in a Multicultural Age", Secularism, Religion and Multicultural Citizenship (2009): 1-24.

Baumann, Gerd. El enigma multicultural. Un replanteamiento de las identidades nacionales, étnicas y religiosas. Barcelona: Paidós, 2001.

Brahm Levey, Geoffry. "Secularism and religion in a multicultural age". In Secularism, religion and multicultural citizenship, edited by Geoffry Brahm Levey and Tariq Modood, 1-24. Cambridge: University Press, 2010.

Bundesverfassungsgericht, 2 BvR 1436/02 Absatz-Nr. (1-140) (3.6.2003). Available at: http://www.bundesverfassungsgericht.de 
Bundesverfassungsgericht $1 B v R 471 / 10$ (27.01.2015). Available at: https://www. bundesverfassungsgericht.de/SharedDocs/Entscheidungen/DE/2015/01/ rs20150127_1bvr047110.html

Casanova, José. Religiones públicas en el mundo moderno. Madrid: PPC, 2000.

- . "Immigration and the new religious pluralism". In Secularism, religion and multicultural citizenship, edited by Geoffry Brahm Levey and Tariq Modood, 139-163. Cambridge: University Press, 2010.

Council of Europe. White Paper on Intercultural Dialogue. Living Together as Equals in Dignity (2008). Available at http://www.coe.int/t/dg4/intercultural/ Source/Pub_White_Paper/White\%20Paper_fi nal_revised_EN.pdf

Council of the European Union. Tampere European Council 15 and 16 October 1999. Presidency Conclusions (1999). Available at http://www.europarl.europa. eu/summits/tam_en.htm\#c

Council of the European Union. Common Basic Principles for Immigrant Integration Policy in the EU (2004). Available at https://ec.europa.eu/migrantintegration/librarydoc/common-basic-principles-for-immigrant-integrationpolicy-in-the-eu

Edmunds, June. "The limits of post-national citizenship: European Muslims, human rights and the Hijab". Ethnic and Racial Studies, n. 35, 7 (2011): 1181-1199.

Freiheitlichen Partei Österreichs (FPÖ). Wahlprogramm. Available at https://www. fpoe.at/

Front National (FN). 144 Engagements présidentiels (2017). Available at http:// www.frontnational.com/

Innerarity, Carmen. "La polémica sobre los símbolos religiosos en Francia. La laicidad republicana como principio de integración". Revista Española de Investigaciones Sociológicas, 111 (2005): 139-61.

Innerarity, Carmen and Beatriz Acha. "Los discursos sobre ciudadanía e inmigración en Europa: universalismo, extremismo y educación”. Política y Sociedad, 47 (2010): 63-84.

Joppke, Christian. "State neutrality and Islamic headscarf laws in France and Germany". Theory and Society, 36 (2007): 313-342.

Manz, Stefan. "Constructing a normative national identity: The Leitkultur debate in Germany, 2000/2001". Journal of Multilingual and Multicultural Development, 25, 5 (2004): 481-496.

Martín Muñoz, Gema. "La islamofobia inconsciente". In La islamofobia a debate. La genealogía del miedo al islam y la construcción de los discursos antiislámicos, edited by Ramón Grosfoguel and Gema Martín Muñoz, 35-46. Madrid: Biblioteca Casa Arabe, 2012.

Maclure, Jocelyn and Charles Taylor. Laicidad y libertad de conciencia. Madrid: Alianza, 2011.

Modood, Tariq. "Post-Immigration 'difference' and Integration: The Case of Muslims in Western Europe". In New Paradigms in Public Policy, edited by Peter Taylor-Gooby. Oxford: University Press, 2013.

- . "Multiculturalism and Moderate Secularism". Robert Schuman Centre for Advanced Studies Research Paper No. RSCAS 2015/47 (2015). Available at http://dx.doi.org/10.2139/ssrn.2631081 
Moreras Jordi. "Migraciones y pluralismo religioso. Elementos para el debate". Documentos CIDOB Migraciones n. 9 (2006). Barcelona: CIDOB. Available at https:/www.cidob.org/publicaciones/series_pasadas/documentos/migraciones/ migraciones_y_pluralismo_religioso_elementos_para_el_debate

Mouritsen, Per. "Beyond postnational citizenship. Access, consequence, conditionality". In European multiculturalisms: Cultural, religious and ethnic challenges, edited by Triandafyllidou, Anna, Tariq Modood and Naser Meer, 88115. Edinburgh: University Press, 2011.

Naïr, Sami. Refugiados. Frente a la catástrofe humanitaria, una solución real. Barcelona: Crítica, 2016.

Österreichische Volkspartei. Wahlprogram (2017). Available at https://www.oevp. at/

Portier, Philippe. "State regulation of religion in Western European countries". In Foret, François and Xabier Itçaina, (eds.), Politics of religion in Western Europe. Modernities in conflict, 93-107. London: Routledge, 2012.

Sayiid, S. "Contemporary politics of secularism". In Secularism, religion and multicultural citizenship, edited by Geoffry Brahm Levey and Tariq Modood, 186199. Cambridge: University Press, 2010.

Schnapper, Dominique. La comunidad de los ciudadanos. Acerca de la idea moderna de nación. Madrid: Alianza, 2001.

Stasi, Bernard. Commission de réflexion sur l'application du principe de laïcité dans la Republique: rapport au Président de la République. 2003. Available at http://www.ladocumentationfrancaise.fr/rapports-publics/034000725/index. shtml

Tibi, Bassam. Europa ohne Identität? Die Krise der multikulturellen Gesellschaft. München: Bertelsmann, 1998.

—. "Die Ideologie des Multikulturalismus, nicht die Idee der kulturellen Vielfalt ist in der Sackgasse". In Multikulturalismus: Vision oder Illusion? Heinrchh Böll Stiftung. Heimatkunde. Migrations Politisches Portal, 2010. Available at http:// www.migration-boell.de/web/integration/47_772.asp. ().

Triandafyllidou, Anna. "Diversity, Integration, Secularism and Multiculturalism". In European Multiculturalisms, edited by Anna Triandafyllidou, Tariq Modood and Naser Meer. 1-29. London: Palgrave, 2011.

Wieviorka, Michel. El racismo. Una introducción. Barcelona: Gedisa, 2009.

Wimmer, Andreas. Nationalist exclusion and ethnic conflict: Shadows of modernity. Cambridge: University Press, 2002.

\section{About the author}

Carmen Innerarity Grau is a PhD (with outstanding Doctorate Award) in Philosophy at the University of Navarra (1994). Deutscher Akademischer Austauschdienst (DAAD) fellow at the Ludwig Maximiliam Universität (Munich) and the Westfälische Wilhelms Universität (Münster). Professor at the University of Navarra, University of the Basque Coun- 
try, University of Salamanca, Complutense University of Madrid (Ortega y Gasset University Institute), National University of Distance Education and the Westfälische Wilhelms Universität (Münster). Since 1995 she has developed her teaching and research activity at the Public University of Navarra, where she is in charge of the Research Group "Politics, identity and culture". She is Associate Professor in Sociology since 2008. She has published several works on political theory and culture, citizenship, cultural integration policies and multiculturalism. Currently, she is focused on the management of cultural differences resulting from migrations in European societies. Her last publications include: "Ciudadanía, integración y universalismo: análisis y evaluación normativa de los programas de integración cívica en Alemania y Francia desde una perspectiva liberal" in Revista Española de Ciencia Política (2016), 41, pp. 39-66. ISSN: 1575-6548. Doi: http://dx.doi.org/10.21308/recp.41.02; "Ciudad y ciudadanía. Un análisis de los planes estratégicos de desarrollo urbano desde la perspectiva de género" in Revista de Investigaciones Feministas (2014), 5, pp. 342-370. ISSN: 2171-6080 (with Sancho Martínez, A.); "El debate sobre el velo islámico en Gran Bretaña. El multiculturalismo liberal y la identidad nacional", in Revista de Estudios Políticos, (2013), 162, pp. 149-174; "La inclusión del otro en Francia y Alemania: el debate sobre el velo islámico", in Sánchez de la Yncera, I. and Rodríguez Fouz, M. (eds.): Dialécticas de la postsecularidad. Pluralismo y corrientes de secularización, Barcelona, Anthropos, (2011), pp. 345-377. ISBN: 978-84-7658-933-5; "Los discursos sobre ciudadanía e inmigración en Europa: universalismo, extremismo y educación", in Política y sociedad, (2010), 47, pp. 63-84 (with Acha Ugarte, B.).

\section{Sobre la autora}

Carmen Innerarity Grau es Doctora en Filosofía y Letras por la Universidad de Navarra (1994), con Premio Extraordinario de Doctorado. Como becaria del Deutscher Akademischer Austauschdienst (DAAD), amplió sus estudios en la Ludwig Maximiliam Universität (Munich) y la Westfälische Wilhelms Universität (Münster). Docencia en la Universidad de Navarra, Universidad del País Vasco, Universidad de Salamanca, Universidad Complutense de Madrid (Instituto Universitario Ortega y Gasset), Universidad Nacional de Educación a Distancia y Westfälische Wilhelms Universität (Münster). Desde 1995 ha desarrollado su actividad docente e investigadora en el Departamento de Sociología de la Universidad Pública de Navarra, donde es responsable del Grupo de Investigación "Política, identidad y cultura". Profesora Titular de Sociología desde el año 2008. Autora de diversos trabajos sobre teoría y cultura política, ciudada- 
nía, políticas de integración cultural y multiculturalismo. En la actualidad sus investigaciones se centran en la gestión de la diferencia cultural generada por la inmigración en las sociedades europeas. Entre sus publicaciones más recientes, destacan: "Ciudadanía, integración y universalismo: análisis y evaluación normativa de los programas de integración cívica en Alemania y Francia desde una perspectiva liberal" en Revista Española de Ciencia Política (2016), 41, pp. 39-66. ISSN: 1575-6548. Doi: http://dx.doi. org/10.21308/recp.41.02; "Ciudad y ciudadanía. Un análisis de los planes estratégicos de desarrollo urbano desde la perspectiva de género" en $R e$ vista de Investigaciones Feministas (2014), 5, pp. 342-370. ISSN: 21716080 (junto con Sancho Martínez, A.); "El debate sobre el velo islámico en Gran Bretaña. El multiculturalismo liberal y la identidad nacional", en Revista de Estudios Políticos, (2013), 162, pp. 149-174; "La inclusión del otro en Francia y Alemania: el debate sobre el velo islámico", en Sánchez de la Yncera, I. y Rodríguez Fouz, M. (eds.): Dialécticas de la postsecularidad. Pluralismo y corrientes de secularización, Barcelona, Anthropos, (2011), pp. 345-377. ISBN: 978-84-7658-933-5; "Los discursos sobre ciudadanía e inmigración en Europa: universalismo, extremismo y educación", en Política y sociedad (2010), 47, pp. 63-84 (junto con Acha Ugarte, B.). 


\section{Derechos de autor}

Los derechos de autor (para la distribución, comunicación pública, reproducción e inclusión en bases de datos de indexación y repositorios institucionales) de esta publicación (Cuadernos Europeos de Deusto, CED) pertenecen a la editorial Universidad de Deusto. El acceso al contenido digital de cualquier número de Cuadernos Europeos de Deusto es gratuito inmediatamente después de su publicación. Los trabajos podrán leerse, descargarse, copiar y difundir en cualquier medio sin fines comerciales y según lo previsto por la ley; sin la previa autorización de la Editorial (Universidad de Deusto) o el autor. Así mismo, los trabajos editados en CED pueden ser publicados con posterioridad en otros medios o revistas, siempre que el autor indique con claridad y en la primera nota a pie de página que el trabajo se publicó por primera vez en $C E D$, con indicación del número, año, páginas y DOI (si procede). Cualquier otro uso de su contenido en cualquier medio o formato, ahora conocido o desarrollado en el futuro, requiere el permiso previo por escrito del titular de los derechos de autor.

\section{Copyright}

Copyright (for distribution, public communication, reproduction and inclusion in indexation databases and institutional repositories) of this publication (Cuadernos Europeos de Deusto, CED) belongs to the publisher University of Deusto. Access to the digital content of any Issue of Cuadernos Europeos de Deusto is free upon its publication. The content can be read, downloaded, copied, and distributed freely in any medium only for non-commercial purposes and in accordance with any applicable copyright legislation, without prior permission from the copyright holder (University of Deusto) or the author. Thus, the content of $C E D$ can be subsequently published in other media or journals, as long as the author clearly indicates in the first footnote that the work was published in $C E D$ for the first time, indicating the Issue number, year, pages, and DOI (if applicable). Any other use of its content in any medium or format, now known or developed in the future, requires prior written permission of the copyright holder. 